\title{
LOCALLY CARRAGEENAN TESTED FOR ITS FOOD GRADE BY FOOD AND AGRICULTURE ORGANIZATION METHOD
}

WIWIEK INDRIYATI ${ }^{1}$, YOPPI ISKANDAR ${ }^{2}$, WILDAN FAWZI BURHANUDDIN ${ }^{1}$, RESMI MUSTARCIHIE ${ }^{1 *}$

${ }^{1}$ Department of Pharmaceutical Analysis and Medicinal Chemistry, Faculty of Pharmacy, Universitas Padjadjaran, Indonesia. ${ }^{2}$ Departmentof Biological Pharmacy, Faculty of Pharmacy, Universitas Padjadjaran, Indonesia. Email: resmi.mustarichie@unpad.ac.id

Received: 20 March 2017, Revised and Accepted: 26 April 2017

\section{ABSTRACT}

Objective: This study aims to determine whether seagrass lalamakan (Dictyota dichotoma), ades (Gelidium sp.), agar (Gracilaria sp.), and saribuhu (Sargassum sp.) obtained from the Sindangkerta beach, Tasikmalaya, can produce carrageenan food grade according to the Food and Agriculture Organization (FAO), Food Chemical Codex (FCC), and European Economic Community (EEC).

Methods: Seaweed was extracted with distilled water and $0.1 \mathrm{~N} \mathrm{KOH}$ at high temperature $\left(90^{\circ} \mathrm{C}\right)$. The extract was tested for its characteristics such as solubility test, test sulfate, gel formation, and its infrared (IR) spectrum.

Results: The yield obtained from solvent extraction with distilled water ranged from $21 \%$ to $27 \%$, whereas for $0.1 \mathrm{~N}$ KOH solvent between $10 \%$ and $11 \%$ by weight. The results of the study indicated that the fiber obtained from both extractions was carrageenan, as shown by the results of the solubility test, the formation of gel and the infrared spectrum showed a sulfate ester, 3,6-anhydrogalactose, galactose-4-sulfate, and 3,6-anhydrogalactose-2sulfate which was characteristic of carrageenan. IR spectrum confirmed the availability of carrageenan. Results of the sulfate test content in all sample fibers using either distilled water or $0.1 \mathrm{~N} \mathrm{KOH}$ were below $15.0 \%$.

Conclusion: These results indicated that the generated carrageenan did not meet food grade standards set by the FA0, FCC, and EEC which was 15$40 \%$. However, in fact, the carrageenan from the Sindangkerta beach has been produced and marketed in the local market.

Keywords: Seaweed, Carrageenan, Extraction, Infrared spectrophotometer, Distilled water, $\mathrm{KOH}$.

(C) 2017 The Authors. Published by Innovare Academic Sciences Pvt Ltd. This is an open access article under the CC BY license (http://creativecommons. org/licenses/by/4. 0/) DOI: http://dx.doi.org/10.22159/ajpcr.2017.v10i8.18590

\section{INTRODUCTION}

Diversity of Indonesian marine resource potential to produce a wide variety of bioactive compounds derived either from plants or animals. This is an opportunity and challenge in the utilization of marine natural products for food, pharmaceutical, and cosmetics industry purposes [1-7]. Approximately, 555 species of seaweed in Indonesia and most of the products have been exported as seaweed dried seaweed and processed [8-10]. In Indonesia, many studies conducted on red seaweed mainly Eucheuma sp. Seaweed grouped by chemical compounds they contain, so well known the producer of carrageenan seaweed (karagenofit), agar (agarofit), and alginate (alginofit). Based on these groupings, the red seaweed (Rhodophyceae) such as Eucheuma cottonii/Kappaphycus alvarezii and Eucheuma spinosum classified as a producer of carrageenan seaweed because it has high levels of carrageenan, approximately $62-68 \%$ dry weight $[6,11-13]$.

Currently, Sindangkerta Village, District Cipatujah, Tasikmalaya, one of the villages on the south coast of the island of Java has a huge potential in the development of marine utilization of material products, particularly seaweed having high-selling power. Without processing seaweed into a better product, one of which carrageenan, of course, the sale value of raw or dried seaweed is not too high. When it becomes flour, carrageenan has a sale value higher than the selling seaweed before it is processed (raw) [14-16]. Here are some seaweed species most widely used in the village Sindangkerta, namely, lalamakan (Dictyota dichotoma), ades (Gelidium sp.), agar (Gracilaria sp.), and saribuhu (Sargassum sp.). With the aim to produce a product, that is, more commercial value is higher, we conducted a study of seaweed to be carrageenan, quality food grade. This study was done considering there has been no research on the specification of the carrageenan Sindangkerta product.

\section{MATERIALS AND METHODS}

\section{Instrument}

The instrument used was infrared (IR) spectrophotometer and Shimadzu Fourier transform infrared (FTIR)-8400.

\section{Plant material}

Plant material used in this study was simplisia seaweed lalamakan (D. dichotoma), ades (Gelidium sp.), Agar (gracilaria sp.), and saribuhu (Sargassum sp.) obtained from the Sindangkerta beach - Tasikmalaya. Type of seaweed was guided by LIPI book [17].

\section{Methods}

Seaweed samples were obtained randomly from Sindangkerta beach, at different growing distances and depths without regard to sample age.

\section{Plant determination}

The seaweed material was determined in the Taxonomy Laboratory, Department of Biology, Faculty of Science, University of Padjadjaran.

Seaweed was washed with clean water, clean of impurities such as sand and salt, then cut to small $+1 \mathrm{~cm}$, then dried in an oven at $600^{\circ} \mathrm{C}$ to constant weight.

\section{Extraction of carrageenan with distilled water}

Extraction and its parameters based on the Departemen Kesehatan RI [18-20].

Seaweed was dried and weighed $2.5 \mathrm{~g}$ and then soaked in distilled water for 15 minutes and filtered with a cloth. 
The extraction was done in the Erlenmeyer which was heated in a water bath shaker. First, the solvent preheated, after reaching a temperature of $90^{\circ} \mathrm{C}$, seaweed inserted, and extraction time started counting. Comparison of seaweed and solvent is 1:30 $(\mathrm{g} / \mathrm{mL})$. The volume of solvent was kept constant by adding hot distilled water each time. After a certain time, the extraction was stopped by means of the filtrate separated from the dregs of seaweed. The filtrate was then collected into a beaker containing $96 \%$ ethanol with a ratio of 3 times the volume of the filtrate while stirring to form fibers hydrocolloids (carrageenan fibers). After allowed to stand about 30 minutes, the fiber was filtered and washed with distilled water until the washing water has a neutral $\mathrm{pH}$. Carrageenan wet dried in an oven at $60^{\circ} \mathrm{C}$ until constant weighed to obtain the dry carrageenan (carrageenan paper). All of the above steps were repeated for each type of seaweed.

\section{Extraction of carrageenan with $0.1 \mathrm{~N} \mathrm{KOH}$}

Extraction with $0.1 \mathrm{~N} \mathrm{KOH}$ was carried out similar to water extraction, but the seaweed was used two times more weigher.

\section{Analysis characteristics of carrageenan}

The yield

The yield of carrageenan obtained by comparing the weight of carrageenan obtained with seaweed weighed heavy. The yield was calculated by

$\%$ Yield=(weight carrageenan $) /($ Weight seaweed $) \times 100 \%$

\section{Solubility}

Testing was carried out by trying to dissolve the carrageenan to distilled water and $96 \%$ ethanol.

\section{Assay test sulfate}

Nearly $0.5 \mathrm{~g}\left(\mathrm{~W}_{1}\right)$ of sample hydrolyzed with $50 \mathrm{ml}$ of $\mathrm{HCl} 0.1 \mathrm{~N}$ for 15 minutes at boiling temperature. Some $10 \mathrm{~mL} \mathrm{BaCl}_{2} 0.25 \mathrm{M}$ added little and simmered for 5 minutes. After cooling for $5 \mathrm{hrs}$, the precipitate is filtered using Whatman filter paper (no. 42 ashless) and subsequently burned in a furnace at $700^{\circ} \mathrm{C}$ for $1 \mathrm{hr}$. The remaining annealing in the form of heavy white ash was barium sulphate (W2).

Levels are calculated by

$\%$ Sulfate $=\left(\mathrm{W}_{1} / \mathrm{W}_{2}\right) \times 100 \times 0.4116$

\section{Identification of formation gel}

Add a few grams of sample to a few $\mathrm{ml}$ of hot water $\left(80^{\circ} \mathrm{C}\right)$ constant shake until dissolved and then cooled the solution at room temperature.

\section{FTIR}

About 1-2 mg of sample with a carefully blended with 300-400 mg KBr and pelleted by means of a rotary vacuum pump. Transparent pellets were formed and then inserted into the instrument. Samples and standard measured and automatically recorded in the form of the spectrum.

\section{RESULTS AND DISCUSSION}

\section{Seaweed collection results}

Seaweed is taken directly from the beach Sindangkerta, Tasikmalaya, between the months of October to December. Samples are taken at the distance grows and grows different depths and also with the different ages.

\section{Plants determination results}

Determination plants do in the Jatinangor Herbarium, Plant Taxonomy Laboratory, Department of Biology. The purpose of this determination was to determine the species and families of plants used in the study. The result of determination showed that seaweed was a seaweed species lalamakan D. dichotoma (Hudson) J.V. Lamouroux of the family Phaeophyceae, species Gracilaria sp. (Greville, 1830) of the family Gracilariaceae, species Gellidium sp. of families Gelidiaceae, and species saribuhu Sargassum sp. of families Sargassaceae.

\section{Extraction results}

From extraction, using a distilled water to yield obtained Gellidium sp. amounting to $22.22 \%$, Gracilaria sp. amounting to $21.35 \%$, D. dichotoma amounting to $21.49 \%$, and Sargassum sp. amounting to $26.66 \%$.

As for the results of the yield of the extraction with $0.1 \mathrm{~N} \mathrm{KOH}$ solvent that was Gellidium sp. $10.83 \%$, Gracilaria sp. amounting to $10.20 \%$, D. dichotoma by $10.72 \%$, and Sargassum sp. amounting to $10.16 \%$.

Compared with distilled water, the low yield of solvent extraction using $\mathrm{KOH}$ due to the breakdown of the polymer by alkaline solutions. Hence, that the fibers were obtained during the deposition process becomes a bit. Unlike, the fibers obtained from the precipitation filtrate extraction with distilled water.

Total yield indicated how well the treatment was carried out on samples of seaweed. If the yield obtained great results, indicating that the processing was carried out has been quite good. If the yield of the resulting slightly, indicating the possibility of processing that is done is not good enough.

Manuhara et al. [21] studied K-carrageenan (RC) extracted from red algae originated from Karimun Jawa Island. They indicated that higher $\mathrm{KCl}$ concentration in extraction resulted in the increase of the carrageenan yield. Actually, the FAO Corporate Document Repository (available at http://www.fao.org/docrep/006/y4765e/y4765e0a. $\mathrm{htm}$ ) has given a guide to the seaweed industry. Webber et al. [22] proposed an alternative method of extraction of carrageenan without previous alkaline treatment and ethanol precipitation using response surface methodology. They claimed that the carrageenan extract properties determined by the polynomial model were $31.17 \%$. Mustapha et al. [23] stated in their alkaline extraction of red seaweed, Eucheuma cottonii, to yield semi-refined carrageenan (SRC) of kappa type. Temperatures $60-80^{\circ} \mathrm{C}$ was suitable for extraction of SRC. At $80^{\circ} \mathrm{C}$ using $1.0 \mathrm{M} \mathrm{KOH}$ produced SRC contained the highest purity of 3,6-anhydrogalactose, a lower heavy metal concentration gave highest rupture force.

\section{Characteristics analysis of fiber}

The results of organoleptic test (color)

The test results of fiber colors are extracted with a solvent distilled to Gelidium sp. brown, Gracilaria sp. amber, amber D. dichotoma, and Sargassum sp. brown.

The test results of fiber colors are extracted with $0.1 \mathrm{~N} \mathrm{KOH} \mathrm{solvent} \mathrm{for}$ Gelidium sp. brown, Gracilaria sp. amber, D. dichotoma brown color, and Sargassum sp. brown.

\section{The results of organoleptic test (odor)}

For the results of the smell test on fibers obtained from solvent extraction with distilled water that each fiber has a distinctive odor. The odor was different from the extraction results with $0.1 \mathrm{~N} \mathrm{KOH}$.

\section{Test results solubility and gel formation}

The test results solubility and gel forming fibers distilled solvent extraction (with ethanol 96\%) for the four types of the same seaweed that was not soluble and does not form a gel.

The test results solubility and gel forming fibers $0.1 \mathrm{~N} \mathrm{KOH}$ solvent extraction (with ethanol 96\%) for the four types of the same seaweed that was not soluble and did not form a gel.

The test results solubility and gelling of the hot distilled water $\left(80^{\circ} \mathrm{C}\right)$ fiber extraction with distilled solvent to the four types of the same seaweed that was not dissolved, but it turned into a kind of gel fibers.

Solubility test results against hot distilled water $\left(80^{\circ} \mathrm{C}\right)$ fiber $0.1 \mathrm{~N} \mathrm{KOH}$ solvent extraction for the four types of the same seaweed that was not dissolved, but it turned into a kind of gel fibers. 
From the results, gel formation can be seen that the fibers resulting from the extraction were done included in the kappa carrageenan or iota carrageenan. As for the lambda carrageenan did not belong to it, because the results obtained should not form a gel for lambda carrageenan, according to the nature of the carrageenan listed in USP, that kappa carrageenan and iota carrageenan yielding gel whereas for lambda carrageenan does not form a gel.

For fiber from Sigma comparative carrageenan, the resulting gel texture is easily broken, then the fiber Gellidium sp. produces a gel which easily broken, as well as fibers produced from Gracillaria sp., D. dichotoma, and Sargassum sp., namely, textured gel easily broken.

\section{Sulfate assay test results}

Results of the analysis of the content of sulfate showed fiber obtained from solvent extraction with $0.1 \mathrm{~N} \mathrm{KOH}$, respectively, were Gellidium sp. 4.474\%, Gracilaria sp. 4.929\%, 2.065\% D. dichotoma, and Sargassum sp. $1.070 \%$. Results of the analysis showed the content of sulfate fiber obtained from solvent extraction with distilled water, respectively, are Gellidium sp. 2.124\%, Gracilaria sp. 4.540\%, 7.043\% D. dichotoma, and Sargassum sp. $1.015 \%$. The results can be seen in Tables 1 and 2 .

The concentration of the solvent used $\mathrm{KOH}$ significant effect on levels of sulfate of fiber carrageenan. Large concentrations of alkaline solution used at the time of extraction can make the sulfate content of carrageenan smaller. The addition of an alkaline solution of carrageenan in the manufacturing process could eliminate or reduce the levels of sulfate ester at C6 of a chain of 1-6-D-galactose. Sulfate esters which reacted with alkali to form sulfate salts thus more easily separated during the screening process. The loss of sulfate ester would form a ring which had a 3.6-anhydrogalactose straight chain, resulting in the formation of gel will easily occur. This result aligned with results of research conducted by Distantina et al. [24] which showed the influence of carrageenan sulfate content generated from solvent extraction with distilled water and solvent bases. Which also states that the use of $0.1 \mathrm{~N} \mathrm{KOH}$ solvent extraction with an increasingly long time, the levels of sulfates in carrageenan also decrease.

The results of the analysis of sulfate content of fiber extraction solvent seaweed well with distilled water and $0.1 \mathrm{~N} \mathrm{KOH}$ food grade not meet the standards under the Food Chemical Codex (FCC), the European Economic Community (EEC), and the Food Agriculture Organization (FAO) were 15-40\%. Yasita and Rachmawati [25] claimed that they were able to have a food grade carrageenan from red algae (E. cottonii) using $\mathrm{NaOH}$ instead of $\mathrm{KOH}$ and also using $\mathrm{H}_{2} \mathrm{O}_{2}$. Mishra et al. [26], however, in their study, on yield and quality of carrageenan from $K$. alvarezii subjected to different physical and chemical treatments, showed that treatment with $\mathrm{KOH}$ gave better yield and quality gel.

Table 1: Results of sulfate test on fiber extraction with distilled water

\begin{tabular}{ll}
\hline Fiber sample & Result (\%) \\
\hline Gellidium sp. & 2.124 \\
Gracilaria sp. & 4.540 \\
Dictyota dichotoma & 7.043 \\
Sargassum sp. & 1.015 \\
\hline
\end{tabular}

Table 2: Results of sulfate test on fiber extraction with $0.1 \mathrm{~N} \mathrm{KOH}$

\begin{tabular}{ll}
\hline Fiber sample & Result (\%) \\
\hline Gellidium sp. & 4.474 \\
Gracilaria sp. & 4.929 \\
Dictyota dichotoma & 2.065 \\
Sargassum sp. & 1.070 \\
\hline
\end{tabular}

\section{Infrared spectroscopy}

For the results of the analysis by infrared spectroscopy, as can be seen in Table 2, almost all fibers showed absorption at wavenumbers that are characteristic of carrageenan, either for sulfate ester (1220$1260 / \mathrm{cm}), 3,6-$ anhydrogalactose $(928-933 / \mathrm{cm})$, galactose 4 -sulfate $(840-850 / \mathrm{cm})$, or 3,6-anhiydrogalactose-2-sulfate $(800-805 / \mathrm{cm})$. These result in accordance with another researcher [27] and also refer to the reference of JECFA [14] on the FAO JECFA Monograph 4 to carrageenan. According to Pancomulyo et al. [28], carrageenan hydrocolloid was a compound which was a composition of long-chain polysaccharide compounds extracted from seaweed. Furthermore, according to Kordi and Ghufran [29], carrageenan was a linear polysaccharide and was a molecule galactans with units mainly in the form of glucose. Volery et al. (2004) [30] reported characterization of commercial carrageenans by FTIR spectroscopy using single-reflection attenuated total reflection and mentioned that the total preparation and analysis time was $<5$ minutes per sample.

The fibers obtained in this study have absorption at wavenumbers between 1000-1100/cm which are a common trait of the polysaccharides that indicate when their absorption at the wavenumbers length is a polysaccharide compound.

Then, Kordi and Ghufran also added, polysaccharide be composed of galactose units with a bond $\alpha(1,3)$ D-galactose and $\beta(1,4)$ 3,6-anhidrogalaktosa alternately, both contain ester sulfate or without sulfate. The results shown by the infrared spectrum of each fiber obtained from the extraction with distilled solvent or solvent $0.1 \mathrm{~N} \mathrm{KOH}$ can be concluded that the fiber was carrageenan, as each fiber showed absorption at wavenumber that was characteristic of carrageenan by JECFA [14] on the FAO JECFA Monograph 4 (Tables 3-10).

\section{CONCLUSIONS}

Based on the extraction results obtained using the solvent extraction method with distilled water and $0.1 \mathrm{~N} \mathrm{KOH}$ solvent, it concluded that the extraction method could be used to obtain carrageenan from seaweed,

Table 3: IR spectrum of carrageenan standard (Sigma)

\begin{tabular}{lll}
\hline Wave number $\left(\mathbf{c m}^{-1}\right)$ & Spectrum & Functional group \\
\hline $928-933$ & 927.78 & 3,6-anhydrogalactose \\
$840-850$ & 846.76 & Galactose-4-sulfate \\
\hline IR: Infrared &
\end{tabular}

Table 4: IR spectrum of Gellidium sp. extracted by distilled water

\begin{tabular}{lll}
\hline Wave number $\left(\mathbf{c m}^{-\mathbf{1}}\right)$ & Spectrum & Functional group \\
\hline 928-933 & 932.60 & 3,6-anhydrogalactose \\
\hline IR: Infrared &
\end{tabular}

Table 5: IR spectrum Gracilaria sp. extracted by distilled water

\begin{tabular}{lll}
\hline Wave number $\left(\mathbf{c m}^{-1}\right)$ & Spectrum & Functional group \\
\hline $1220-1260$ & 1257.61 & Sulfate ester \\
$928-933$ & 931.63 & 3,6 -anhydrogalactose \\
$840-850$ & 846.76 & Galactose-4-sulfate \\
$800-805$ & 802.40 & 3,6 -anhydrogalactose-2-sulfate \\
\hline
\end{tabular}

IR: Infrared

Table 6: IR spectrum Sargassum sp. extracted by distilled water

\begin{tabular}{lll}
\hline Wave number $\left(\mathbf{c m}^{-\mathbf{1}}\right)$ & Spectrum & Functional group \\
\hline $1220-1260$ & 1232.53 & Sulfate ester \\
$800-805$ & & \\
\hline IR: Infrared & &
\end{tabular}


Table 7: IR spectrum Gellidium sp. extracted by KOH 0.1 N

\begin{tabular}{lll}
\hline Wave number $\left(\mathbf{c m}^{-1}\right)$ & Spectrum & Functional group \\
\hline $1220-1260$ & 1239.29 & Sulfate ester \\
$928-933$ & 932.60 & 3,6-anhydrogalactose \\
$840-850$ & 848.69 & Galactose-4-sulfate \\
\hline
\end{tabular}

IR: Infrared

Table 8: IR spectrum Gracilaria sp. extracted by КОН 0.1 N

\begin{tabular}{lll}
\hline Wave number $\left(\mathbf{c m}^{-1}\right)$ & Spectrum & Functional group \\
\hline $928-933$ & 928.78 & 3,6-anhydrogalactose \\
$840-850$ & 846.76 & Galactose-4-sulfate \\
\hline
\end{tabular}

IR: Infrared

Table 9: IR spectrum Dictyota dichotoma extracted by КОН $0.1 \mathrm{~N}$

\begin{tabular}{lll}
\hline Wavenumber $\left(\mathbf{c m}^{-1}\right)$ & Spectrum & Functional group \\
\hline $928-933$ & 930.67 & 3,6 -anhydrogalactose \\
\hline IR: Infrared
\end{tabular}

IR: Infrared

Table 10: IR spectrum Sargassum sp. extracted by $0.1 \mathrm{~N}$

\begin{tabular}{lll}
\hline Wave number $\left(\mathbf{c m}^{-1}\right)$ & Spectrum & Functional group \\
\hline $810-820$ & 818.80 & Galactose-6-sulfate \\
\hline IR: Infrared &
\end{tabular}

with the yield obtained ranged from $21-27 \%$ and $10-11 \%$ with distilled water and $0.1 \mathrm{~N} \mathrm{KOH}$, respectively.

It concluded as well as that the fibers had some character carrageenans, except for the sulfate content of the fiber was not yet eligible carrageenan food grade standards established by the FAO, FCC, and EEC.

Based on this result, it suggests further for optimization of the method used to obtain results that can qualify the standards set by the FAO, FCC, and EEC.

\section{REFERENCES}

1. D'Amelio FS. Botanicals: A Phytocosmetic Desk Reference. New York: CRC Press; 1991. p. 9.

2. Anggadiredja JT, Achmad ZH, Istini S. Seaweed (Rumput Laut). Jakarta: Penebar Swadaya; 2007. p. 6-21.

3. Garg AK, Negi LM, Chauhan M. Gel containing ethosomal vesicles for transdermal delivery of aceclofenac. Int J Pharm Pharm Sci 2010;2(2):102-8

4. Fitrya F. Inspection characteristics crude algae Padina Australis hauck. Sci Res J 2010;13(3):C13309.

5. Bhattacharjee S, Paul S, Dutta S, Chaudhuri TK. Anti-inflammatory and protective properties of Aloe vera leaf crude gel in carrageenaninduced acute inflammatory rat models. Int $\mathrm{J}$ Pharm Pharm Sci 2014;6(9):368-71.

6. Stanley N. Production, Properties and Uses of Carrageenan, Production and Utilization of Products from Commercial Seaweeds, FAO Corporate Document Repository. Ch. 3. Available from: http://www.fao.org/ docrep/x5822e/x5822e05.htm. [Last downloaded on 2016 Mar 04].

7. Laaboudi W, Ghanam J, Aissam H, Merzouki M, Benlemlih M. Antiinflammatory and analgesic activities of olive tree extract. Int J Pharm Pharm Sci 2016;8(7):414-9.

8. Akrim D. The seaweed business development in Indonesia. J Shipping Ocean Eng 2014;4:198-202.

9. Indriani H, Suminarsih E. Seaweed (Cultivation, Processing and Marketing (Rumput Laut (Budi Daya, Pengolahan dan Pemasaran).
Jakarta: Penebar Swadaya; 2003. p. 4-8, 11-2.

10. Evacuasiany E, Kartadarma E, Atmawidjaja S. PROSIDING Seminar Nasional Tumbuhan Obat Indonesia XXVII (Utilization of Seaweed Type Eucheuma sp. As Antirheumatic and Degenerative Bones). Jakarta: Puslitbang Kimia Terapan LIPI; 2001. p. 1-2.

11. Aslan L. Budidaya Rumput Laut. Edisi Revisi. Yogyakarta: Penerbit Kanisius; 1998. p. 23-4.

12. Winarno FG. Seaweed Processing Technology (Teknologi Pengolahan Rumput Laut). Jakarta: Pustaka Sinar Harapan; 1996. p. 120-5.

13. Arfah H. Manufacture of semi-refined carrageenan (SRC) and the diversification of seaweed products as high-fiber foods. Bull Penelitiandan Pengembangan 2015;13(1):121-31.

14. JECFA. FAO JECFA Monographs 4. Rome: FAO; 2007.

15. Sulistyaningsih R. Extraction and Characterization of Carrageenan from Seaweed Eucheuma spinosum from Madura Sumenep Regional Aquaculture (Ekstraksi dan Karakterisasi Karagenan Dari Rumput Laut Euchema spinosum Hasil Budidaya Daerah Sumenep Madura. Surabaya). Thesis. Indonesia: Institut Teknologi Surabaya (ITS); 2006.

16. Diharmi A, Fardiaz D, Andarwulan N, Heruwati ES. Carrageenan characteristics result isolation Eucheuma spinosum (red algae) from Sumenep Madura Waters. J Perikanan dan Kelautan 2011;16(1):117-24.

17. Atmadja WS, Kadi A, Sulistidjo S, Rachmaniar R. The Introduction of Seaweed Types (Pengenalan Jenis - Jenis Rumput Laut). Jakarta: Puslitbang Oseanologi LIPI; 1996.

18. Depkes RI. Parameter Standar Umum Ekstrak Tumbuhan Obat. Jakarta: Departemen Kesehtan RI; 2000. p. 10-1.

19. Harborne JB. Phytochemical Methods. Translated by Kosasih Padmawinataand Iwang Soediro. Bandung: Penerbit ITB; 1987. p. 102-3.

20. Oviantari MV, Parwata IP. Optimizing product semi refined carrageenan euchema cottoni varying mechanical drying and moisture content raw materials. J Penelitian Pengembangan Sains Humaniora 2007;1(1):62-71

21. Manuhara GJ, Praseptiangga D, Riyanto RA. Extraction and characterization of refined k-carrageenan of red algae [Kappaphycus alvarezii (doty ex P.C. Silva, 1996)] originated from Karimun Jawa Islands. Aquat Proc 2016;7:106-11.

22. Webber V, de Carvalho SM, Ogliari PJ, Hayashi L, Barreto PL. Optimization of the extraction of carrageenan from Kappaphycus alvarezii using response surface methodology. Ciênc Tecnol Aliment Camp 2012;32(4):812-8.

23. Mustapha S, Chandar H, Abidin ZZ, Saghravani R, Harun MY. Production of semi-refined carrageenan from Eucheuma cottonii. J Sci Ind Res 2011;70:865-70.

24. Distantina S, Fadillah F, Rochmadi R, Fahrurrozi M, Wiratni W. Extraction Process From Carrageenan Eucheuma cottonii (Proses Ekstraksi Dari Karagenan Eucheuma cottonii). Seminar Rekayasa Kimia dan Proses 4-5 Agustus, 2010. Indonesia: Jurusan Teknik Kimia, Fakultas Teknik UNDIP; 2010.

25. Yasita D, Rachmawati ID. Optimization of the Extraction Process in the Manufacture of Carrageenan from Seaweed Eucheuma cottonii to Achieve Food Grade (Optimasi Proses Ekstraksi Pada Pembuatan Karaginan Dari Rumput Laut Eucheuma cottonii Untuk Mencapai Foodgrade). Available from: https://www.core.ac.uk/download/ pdf/11704403.pdf. [Last download on 2016 Mar 4].

26. Mishra PC, Jayasankar R, Seema C. Yield and quality of carrageenan from Kappaphycus alvarezii subjected to different physical and chemical treatments. Seaweed Res Utiln 2006;28(1):113-7.

27. Dewi NC, Darmanto YS, Ambariyanto A. Charcterization and quality of semirefined carrageenan (SCR) products from different coastal waters based on Fourier transform infrared technique. J Coast Dev 2012;16(1):25-31.

28. Pancomulyo T, Maryani H, Kristiani L. Seaweed Cultivation and Processing (Budidaya dan Pengolahan Rumput Laut). Surabaya: Agro Media Pustaka; 2006. p. 34-8.

29. Kordi M, Ghufran H. Success Tips Seaweed Cultivation at Sea and Tambak. Yogyakarta: Andi; 2011. p. 30-5.

30. Volery P, Besson R, Schaffer-Lequart C. Characterization of commercial carrageenans by Fourier transform infrared spectroscopy using single-reflection attenuated total reflection. J Agric Food Chem 2004;52(25):7457-63. 